\title{
STATE POOL PLANS AND MERIT RATING
}

\author{
I. M. RuBINow*
}

With the end of 1935 the movement for so-called social security (more accurately, either "economic security" or "social insurance"), and particularly for unemployment insurance, has definitely entered a new phase. Though some talk continues about the demoralizing influences of the dole and great American principles of individual responsibility, on the whole the emotional battle for some form of unemployment insurance has been won. The Federal Act, however, has not established one final scheme of legislation, and in the immediate future the questions of ways and means of legislative procedure, of costs, etc., rather than appeals on the ground of need, must, therefore, come to the surface.

In this symposium the specific topic assigned to the writer is one concerning the basic organization of the unemployment insurance apparatus. He is to deal with the advantages of so-called "state-wide pools" as against other forms of organization: employer reserves, independent plans, guaranteed employment plans, etc. He is also asked to deal with the seemingly complicated and confusing problem of merit rating. There is, as will be shown presently, a logical inter-relationship between state pools and merit rating. But the joint handling of those two technical problems is also justified by the fact that both deal with proposed deviations of the American unemployment insurance plan from accepted European standards. ${ }^{1}$

It is no criticism of the American movement for unemployment insurance to admit that the stimulus has largely come from European experience and that naturally all American writings and suggestions have been strongly influenced by the existing European legislation and its results in so far as they are known to American students. On the other hand, it should be equally obvious that the United

- A.B., I895, Columbia University; M.D., 1898, New York University; Ph.D., I914, Columbia University. Secretary, B'nai B'rith, since I929. Previously director of various social welfare organizations; chief statistician, Ocean Accident \& Guarantee Corporation; and economic expert to the United States Departments of Agriculture and of Commerce and Labor. Member of the Ohio Commission on Unemployment Insurance, 1932; President, Casualty Actuarial Society, 1914-1916. Author of numerous works on economic problems and social insurance, including The Quest for Security (1934). Contributor to periodicals on sociological, economic, financial, and political topics.

${ }^{1}$ For a general description of European systems of unemployment insurance, see ArMstrong, Insuring the Essentials (1932) 462-552; Epstein, Insecurity: A Challenge to America (r933) 303-398; RuBinow, The QUesT For Security (1934) 303-458. For more detailed studies of the two most important European systems, see Gilson, Unemployment Insurance in Great Britain (I93r); Carroll, Unemployment Insurance in Geraiany (1929). 
States is not obliged to follow blindly the previous experience of any country. Because of the existence of that experience and the lessons it may convey, efforts to modify either the basic principles or the technical details so as to avoid some of the pitfalls into which England or Germany or other countries have fallen, are perfectly legitimate. A new proposal must not be discarded merely because it is new.

At this time, the principal issue, in so far as technical organization of the insurance mechanism is concerned, lies between the so-called Wisconsin ${ }^{2}$ and Ohio ${ }^{8}$ plans, or the plans of individual employer reserves and state-wide insurance funds or pools. While the present study cannot detail the history of the two plans and the conflict between them, it may be noted that the Wisconsin plan had considerable advantage in time over the state pool plans, an advantage of perhaps ten years of discussion in Wisconsin. It had, in addition, the very great influence of such weighty names as those of Professor John R. Commons, Professor Paul Raushenbush, and Miss Elizabeth Brandeis, ${ }^{4}$ the backing of the La Follette dynasty and Wisconsin's general reputation as a leader in progressive legislation; it had the additional influence throughout the country of Professor Commons' many students of law and labor problems. ${ }^{5}$ Last but not least, the plan was the first to become law early in 1932, a factor inevitably influential in many state legislatures where imitation still remains of great importance in legislation. Thus the Wisconsin plan of employer reserves promised or threatened to become in fact what was claimed for it by the American Association for Labor Legislation, namely, the American type of unemployment insurance.

It is therefore extremely significant that a very sudden change of attitude took place practically following the report by the Ohio Commission on Unemployment Insurance in 1932. In I933 unemployment insurance bills flooded almost all the state legislatures, but the bills were fairly equally divided between the two plans. Among the experts under the President's Committee on Economic Security, the influence of Wisconsin was entirely out of proportion to that state's industrial importance, but, nevertheless, at one time in the legislative history of the Federal Act, the state pool threatened to become the only permissible form of organization. In the final text, largely, it is reported, through the influence of Senator La Follette, both

\footnotetext{
I See Hoar, UNemployment InsUrance IN Wisconsin (1932), containing the text of the original act with a few comments, also a few plans of voluntary reserves, and the majority and minority reports of the legislative commissions considering this measure; EwING, JoB InsURANCE (1933), containing very valuable material on the legislative history of the Wisconsin Act.

${ }^{3}$ Rubinow, Stabilization Versus Insurance (193I) 5 Soctal SERvice Rev. 199-213; Rubinow, The Movement Tosvards Unemployment Insurance in Ohio (1933) 7 SOCIAL SERvice Rev. I86-224; Rubinow, The Ohio Versus the Wisconsin Plan-Conflict or Compromise, Sociar. Security in the United States, 1934 (7th Nat. Conf., Am. Ass'n for Social Security, 1934) I23-139.

'See Groves, Unemployment Insurance in Wisconsin (I933) 23 AM. LAB. LEG. Rev. I23.

-Among these is the group headed by Dr. John B. Andrews of the American Association for Labor Legislation. The Association's proposal may be found in An American Plan for Unemployment Reserve Funds (1933) 23 AM. LAB. Leg. Rev. 79.
} 
plans and also other forms were given equal permissive standing. Yet of the ten acts already adopted, ${ }^{6}$ all but three give preference to the state pool plan, though in some cases certain concessions are made to what is loosely described as the Wisconsin principle. Only three states may be said to have decided to adhere to the employer reserve scheme in its original form.

When the situation is thus summarized, one may be inclined to assume that the controversy has practically ended, that the struggle for the state pool principle has been won, at least on the plane of basic theory. However, there is reason to believe that the situation is no longer a conflict merely of two ideas to be decided on their merits. Evidence is not lacking that employers' interests are gradually beginning to shift again towards the Wisconsin point of view. This shifting is not so much to be ascribed to the victory of the Wisconsin theory over the Ohio theory but to the fact that, as will be explained more fully presently, the question of costs or rates is involved; and if American industry, rightly or wrongly, should decide that the Wisconsin plan is the cheaper of the two, the conflict may be reopened in all its fury this year and next in all the remaining thirty-nine legislatures.

\section{II}

As the case for the employer reserve plan is to be stated elsewhere in this symposium, ${ }^{7}$ it might appear sufficient here merely to present the positive arguments in favor of the state pool; and yet this would be a rather difficult task unless embodied in this article is a critical review of what the writer would describe as the errors of the Wisconsin approach.

The prima facie case for the state pool is almost an ironclad and unassailable one. We are dealing with the proposal for insurance of a large number of individuals against the possible hazard of unemployment. Obviously in any insurance scheme the larger the exposure the nearer may one come to an appraisal of the average risk, if any appraisal be possible. If the work can be done by one fund, why have two or more? As we are not dealing here with a branch of the commercial insurance business, there can be no discussion of the right of competition, competitive profits, etc. The economy of a united insurance mechanism must be obvious. It is stated that an insurance fund, like every other business undertaking, may become so large as to be unwieldy. That might serve (and has been used) as an argument against one indivisible national fund, but so long as we must have at least forty-eight state funds, the danger of excessive size is obviously dispensed with.

\footnotetext{
- The following laws have thus far been enacted: Alabama, Laws 1935, Sen. B. No. 395; California. Stat. 1935, c. 352; District of Columbia, Public, No. 386, 74th Cong., Ist Sess. (1935); Massachusetts. Gen. Laws, c. 151A (Laws 1935, c. 479); New Hampshire, Laws 1935, c. 99, as amended by c. 142; New York, N. Y. Consol. Laws, art. 18, c. 31, \$\$500-531 (Laws 1935, c. 468); Oregon, Laws 1935, Spec. Sess., H. B. No. 71; Utah, Laws 1935, c. 38 ; Washington, Laws 1935, c. I45; Wisconsin, Wis. Stat. (1933) c. 108, as amended by Laws I935, c. I92, 272, 446. A brief enabling act was passed by North Carolina, Laws 1935, c. 492 , but no system has been set up thereunder.

${ }^{7}$ See Brandeis, The Employer Reserve Type of Unemployment Compensation Law, supra, p. 54.
} 
Additional support for state-wide pools may readily be found in the experience of all the European countries. It will suffice here to refer briefly to that in Great Britain and Germany. The original British Act of $19 \mathrm{Ir}^{8}$ was limited to a small number of extra-hazardous industries. Since the first considerable extension of that Act in 1920 , the problem of special treatment of individual employers has been discussed until practically this day. ${ }^{9}$ Under certain conditions the Act of rg20 permitted industries to "contract out" of the state scheme and organize approved plans of their own. Under this provision only two industries ${ }^{10}$ (but not individual employers), namely, commercial insurance and banking, had contracted out and remained the exceptions to the national scheme. But the crisis in $x 92 x$ frightened both the government and most industries against the uncertainties of this privilege, and it was withdrawn by the Act of rg2r. ${ }^{11}$

In the considerable discussion during the '20's of the advantages of unemployment insurance "by industry,"12 no little confusion remained as to the exact meaning of that term, whether it meant insurance according to industry but within the general scheme, or insurance to be carried on through separate industries. Many British students and some American investigators advocated that the well-organized industries with low unemployment rates be allowed to organize schemes of their own, and profit to that extent by the lower premium rates. ${ }^{13}$ It is very significant that in these British discussions, some five or ten years ago, the division of opinion was not unlike that found in this country in more recent years; the economists arguing somewhat theoretically in favor of such measures, while practical actuaries, as for instance Actuary Watson, responsible for the British unemployment insurance rates, objected strenuously ${ }^{14}$ that, since the rate of contributions had been computed without this method of preferences, privileges and contracting out, those exemptions would upset the whole actuarial structure. ${ }^{15}$ The only significant difference between the British and American discussions is that such organizations as the Association of British Chambers of Commerce, the National Confederation of Employers' Organizations, and the National Union of Manufacturers-names reminiscent of the corresponding American bodies-favored the existing system of general spread of risks.

\footnotetext{
${ }^{8}$ See Girsos, op. cit. supra note I, at $4 \mathrm{I}$.

- Id. at 8.

${ }^{10} 7 d$. at $8 \mathrm{r}-84$.

III. at 80 .

${ }^{12}$ See Cohen, Insurance by Industry Examined (1923).

${ }^{23}$ Thus, the economist, Henry Lesser, urged such a scheme both to relate rates more equitably to hazards and to stimulate greater interest in stabilization. Sec LESSER, UNEMPLOYMENT INSURANCE IY INDUSTRIEs (1923) 5-7. The American economist, Felix Morley, in making the same plea, urged lower rates for the more stable industries and higher rates for the less stable. MorLey, UNeMployment ReLieg in Great Britain (I924) xi. The great English economist, Pigou, advocated a low basic uniform rate for all industries with an added rate for the less stable but placed his emphasis on rate differentiation rather than on insurance organization. Pigod, Industrial Fluctuations (1927) 343-345.

${ }^{14}$ See Gilson, op. cit. supra note $\mathrm{r}$, at 356.

${ }^{15}$ Another opponent was the well-known student of social insurance in Great Britain, Professor Joseph L. Cohen, who argued that schemes of insurance by industry would destroy the fundamental principle of insurance, namely, the pooling of good and bad risks. Id. at 57 .
} 
Very similar to that has been the attitude towards the problem in Germany. Professor Mollie Ray Carroll sums up the attitude there as follows: ${ }^{16}$

"Germany is of the opinion that gradation of contributions according to risk of industry produces negligible results in controlling unemployment. It is admitted that such a policy might help to regularize certain types of seasonal unemployment or stimulate employers to discover and practice schemes for stabilization within their own establishments. Gains in one plant, however, are thought to be largely at the expense of increased fluctuations in employment in other establishments as long as the problems of trade fluctuations remain unsolved. The attempt to grade contributions in order to induce the employer to eliminate or reduce unemployment is thought to result from a fallacious analogy between unemployment and industrial accidents."

Accordingly, the German unemployment insurance fund remained undivided. Theoretically reductions and rate adjustments were allowed by districts and not by industries or individual employers. But even the district differentiation had never to any extent been carried through.

Thus the two basic motives or defenses of the scheme of employer reserves, namely the expectation of stabilizing influence upon industry and possibilities of more equitable rate adjustment, were not discovered in Wisconsin. They have been under consideration abroad for some fifteen years, and, while a considerable amount of lip service was given to both principles, practical considerations prevented any extensive application. The interesting contribution Wisconsin has made to the theory of unemployment insurance may be somewhat facetiously stated as the proposal to abolish the insurance principle altogether, to substitute the term "unemployment compensation," and to go even further in emphasizing the possible stabilizing influences as presenting the real purpose rather than "mere relief of the unemployed."

The philosophical basis of the Wisconsin plan, therefore, raises a number of fundamental problems: Is there a necessary antagonism between prevention through stabilization and insurance? ${ }^{17}$ If such there be, are the two objectives mutually exclusive or is compromise possible? Even admitting the essential conflict between these objectives, what is the justification for putting prevention ahead of compensation, particularly since the preventive effect must necessarily as yet be hypothetical and not tested by experience? To what extent does the possibility of some prevention meet the problem of residual workmen whose unemployment wasn't and couldn't be prevented? Even assuming the greater desirability of prevention, is the theory justified that prevention is entirely up to the industry or individual employer? How far justified is the basic theory of the preceding argument, namely, that responsibility for the employee may be placed at the individual employer's door?

Even assuming the responsibility of the employer and his ability at least partially to stabilize industry and reduce unemployment, what evidence is there that the

${ }^{10}$ Carroll, op. cit. supra note $\mathrm{I}$, at 83 .

${ }^{17}$ Rubinow, Stabilization Versus Insurance, supra note 3. See also Chapter 44, "Insurance as Prevention" in Rubinow, The Quest For Security (1934) 568-580. 
Wisconsin plan will prove a sufficient incentive to accomplish such results? Finally, if manipulation of the premium, or what is technically known in insurance practice as a specific rate structure, may prove to be such necessary inducement, is it inevitably tied up with the Wisconsin employer reserve plan?

Even before these questions can be fully answered, it would seem quite clear that at best we are dealing with a very abstract, theoretical approach to a very practical problem, and one cannot help wondering to what extent the unemployed wage worker, whose interests may be sacrificed to theory, would agree to the justice of such a situation..$^{18}$

For what, after all, is the fundamental difference between the two plans? The state pool offers at least as much assurance as can be offered within the total income of the fund without making it an unlimited responsibility of the state, which is the insurance carrier. The more a fund is subdivided, the weaker does the degree of guaranty become. An industry fund would necessarily be less guaranteed than a state fund. A corporation employing thousands of people with an individual reserve fund would stand in the nature of an insurer to them. But obviously when this principle of individual reserves is logically carried through to the smallest individual employer, the insurance principle is destroyed altogether. Credit is due the Wisconsin protagonists, therefore, for avoiding the word "insurance" and speaking of "reserves" instead. But reserves for what? Reserves are an aspect of an insurance mechanism. Reserves are intended to protect an insurance contract. But individual reserves of small employers carrying no liability over the amount in the reserve not only are not insurance; they are not even compensation. Every promise is a promise "if and when," and, in the very nature of things, these promises will remain unfulfilled in a great many cases.

Until the Federal Act had passed, one was justified in discussing the Wisconsin plan on the basis of the Wisconsin Act only. Naturally this would not be fair under the Federal Act. The plan may remain though individual terms vary. Its fundamentals are: (r) The entire denial of the method of insurance (in the Wisconsin Act re-insurance by the employer is prohibited).$^{10}$ (2) The employer is responsible for his legal rate of contribution, and he pays it into his individual account. (3) Out of that account benefits will be paid so long as that account makes it possible. (4) If contributions exceed payments and a reserve accumulates to a certain amount, the contribution rate may be reduced and eventually discontinued altogether.

What are the specific provisions for minimum reserves under the federal and present state acts? To answer this question one must remember that the Federal Act does not establish but merely permits the separate reserve plan by allowing certain additional credits against the federal payroll tax. Section gro (a) (3) of the Federal Act reads:

\footnotetext{
${ }^{13}$ Rubinow, The Ohio Versus Wisconsin Plan: Conflict or Compromise, supra note 3.

${ }^{10}$ Wis. Stat. (1935) \$ro5.15 (3).
} 
"Such lower rate, with respect to contributions to a separate reserve account, is permitted only when (A) compensation has been payable from such account throughout the preceding calendar year, and (B) such account amounts to not less than five times the largest amount of compensation paid from such account within any one of the three preceding calendar years, and (C) such account amounts to not less than $7 \frac{1}{2}$ per centum of the total wages payable by him (plus the total wages payable by any other employers who may be contributing to such account) with respect to employment in such State in the preceding calendar year."

It is unnecessary to stop now to analyze and interpret this very confused language which, unfortunately, is characteristic of all of the Federal Social Security Act. The essential provision is that the account must not be less than $71 / 2 \%$ of the annual payroll before any reductions may be credited under the Federal Act. Obviously this has become the standard for state legislation, even though there are several important variations. ${ }^{20}$ Whether such variations will always hold is still somewhat uncertain, because the state acts do require the Social Security Board's approval before the rebate provisions go into affect. The $7 \frac{1}{2} \%$ provision may, therefore, be taken as a typical and normal one. Wisconsin, with a much milder provision for minimum reserves in its original act, has already made the necessary adjustments. The problem to consider now is how effectively this minimum reserve can guarantee that benefits will be paid at least in the majority of cases, and, secondly, with this requirement facing the employer, how much of an incentive remains for efforts toward stabilization.

A bit of arithmetical computation will answer both these questions. With a reserve at $7 \frac{1}{2} \%$ of the payroll and the annual contribution limited to $3 \%$ (after I939) it must take two and one-half years of accumulation, without a single benefit payment, before the minimum reserve will be reached. Naturally such plants will be the exceptional ones which show absolutely no reduction in force and no discharges of employees for two and one-half years. The ordinary misadventures of normal business life will further delay the "happy day" when a reduction, and eventually discontinuance, of the tax may be achieved. To what extent the possibility of reducing the payroll tax in the indefinite future from $3 \%$ to $2 \%$ and $1 \%$ and eventually abolishing it altogether-to what extent that will actually prove an inducement, is a problem in industrial psychology not easily answered. What it obviously will do is to offer a fairly definite promise of a reduced rate, not to the good and efficient employer but to the industry which normally has a low unemployment risk. Assuming on the basis of British experience that the banking business is such, the bankers may look forward to accumulating that necessary reserve within two or three years, and then being relieved of further payments, at least for many years, not because they are good and efficient bankers, careful of the interests of their staff, but merely because they are bankers. In other words, the inducement for purposes of stabilization is rapidly converted into a classification differential, no

${ }^{20}$ Three states have a straightforward Wisconsin employer reserve plan: Oregon, Utah, Wisconsin. 
more, no less. On the other hand, what is the effect upon the promised benefit or compensation? Again, a little arithmetic will help.

The standard benefit, though not provided for in the Federal Act, apparently will be $50 \%$ of the wages with certain limitations. A weeks' wages roughly are $2 \%$ of the annual payroll. The weekly benefit, therefore, is $\mathrm{x} \%$ of that payroll. A $7 \frac{1}{2} \%$ reserve, when achieved, guarantees a payment of benefits for $7 \frac{1}{2}$ weeks even in case of a total shut-down of the plant-a contingency not to be too frequently encountered. Therefore, in such plants where reserves have accumulated-either stabilized plants or plants in stable industries - the security would be fair. But, of course, those are exactly the companies in which the hazard of unemployment is lowest. What about the other branches of industry, those in which the normal rate of contribution may soon prove insufficient and very small, if any, reserves will accumulate? In such industries, particularly in the smaller plants, the promise of compensation will become a snare and a delusion. ${ }^{21}$ In fact, in so far as employer reserve plan provides no increase of the premium rate over the normal $3 \%$, provides for isolation of the reserves and their accumulation in the more stabilized industries, and for eventual shaving of the premium downwards in the best of plants, it follows inevitably that the premium rate must prove insufficient for the more hazardous undertakings.

The conclusion is inevitable. The very hypothetical and theoretical and problematical stabilizing influence in such plants and industries which in the very nature of things need it least, is to be purchased at a price of destroying all elements of assurance in the promised unemployment compensation scheme.

In this conflict, as yet often unrecognized by the interested parties, between the interests of the unemployed wage worker clamoring for his compensation and of industry as a whole requiring stabilization, there might at least be found the elements of a real social conflict. But actually the situation is even more unfavorable to the Wisconsin plan than the above contrast would indicate. Too much has to be acceded to the theory to leave anything to the reality of the stabilizing influence. It must be assumed that it is the employer who is responsible for unemployment; that in his effort lies the primary hope for reducing unemployment; that in face of the obvious advantages of stabilized plant or industry and the losses of irregular plant operation, the employer is not wise enough to realize those advantages unless given a special inducement; and that the possibility of a future saving of $\mathrm{x} \%$ or $2 \%$ on the payroll may prove the one strong inducement necessary.

It is, to be quite frank, a little difficult to consider these arguments seriously

${ }^{21}$ "What really disturbs me is the danger that after the National Government makes the $3 \%$ of payrolls available, the individual States will put through measures that will give thousands of working people a false sense of security, which will later turn out to be a glorified form of organized cruelty when the steady workman finds the funds collected have been frittered away." Mathewson, The Need of Assurance in Unemployment Insurance, Social Securaty IN THE UNITEd STATES, 1935, 156, 157. 
from a point of view of practical business accounting, ${ }^{22}$ but the unique aspect of this controversy, which differentiates the American discussions from the European ones, is not so much in the opinions of academic students of economics, for even among them obviously considerable difference of opinion prevails, ${ }^{23}$ as in the growing enthusiasm of business groups for the employer reserve plan against state pools. The explanation of this must be looked for elsewhere than in the employer's sudden faith that, given the incentive, he and he alone can stabilize industry and abolish or reduce unemployment. Perhaps unconsciously two entirely different motives came into play, and the situation cannot be understood unless these motives are brought to the surface.

First was the very forcible popularization of the doctrine that unemployment was an uninsurable risk, that it couldn't be made actuarially sound, and that, therefore, every element of guaranty or insurance should be deliberately taken out, and merely a savings fund provided which might pay very limited benefits so long as there was money to pay. That, of course, made the problem extremely simple, at least technically. ${ }^{24}$

The second point is perhaps of even greater importance. With a confusion of thought arising out of lack of familiarity with the whole subject-a lack of familiarity for which, of course, American industry and American economics must share responsibility-many arguments were made about the incentive and prospective reward to the good employer, when what was really meant was the dangling of a hope of a substantial reduction in premium rates to certain already stabilized industries. The latter was quite certain, and the bird in hand was preferred to two in the bush. All this was logically connected with the American system of placing the entire cost upon industry, with only a few states suggesting an employee's contribution and nobody seriously fighting for a contribution from the state. With the entire cost thus placed at the door of the employer, presenting an immediate load upon the payroll and production expense, his anxiety to reduce the load was quite easily understood.

$\approx$ Their defenders are found chiefly among teachers of economics, and even one of these, Professor Sumner H. Schlichter of Harvard, has voiced the view that industry reserves should be supplemented by a national pool. Schlichter, Toward Stability (1934) 179. And Professor R. S. Meriam of Harvard asserts that the claim that employers could do away with unemployment if they would seem "to them as baseless as accusing the butcher, the baker, and the grocer of responsibility for undernourishment." Meriam, Unemployment Reserves: Some Questions of Principle (1933) 47 QUARTERLy J. OF Econ. 3I2, 322.

$\approx$ Thus, for instance, Professor Paul H. Douglas, Standards of Unemployment Insurance (1933) I66-168, is definitely opposed to the plan; Professors Alvin H. Hansen and Merrill G. Murray, A NEw Plan for Unemploxment Reserves (1933) 27, approved of the reserve plan; but both these authors together with Russell A. Stevenson and Bryce M. Stewart, in their collective work, A Prosram For UNemployment Insurance and ReLief in the United States (1934), referring to the earlier work, frankly state, at p. iv: "Hansen and Murray in their previous volume presented a plan providing for both company and industry funds. Criticism and discussion of their suggested program and further study have caused them to go over to the second school of thought. The provisions for reserves by individual companies is abandoned in the present plan and a wider pooling of funds advocated."

${ }^{24}$ Even so careful a student as Professor C. A. Kulp of the University of Pennsylvania joined the camp of employer reserve advocates on this ground. Kulp, The Purchase of Security Through Unemployment Compensation (1934) 23 AM. LAB. Leg. Rev. 23. 
Thus the controversy between the Wisconsin and the Ohio plans, is not as simple as it might appear. It involves at least the following consideration. Is unemployment an insurable risk? Is an actuarially sound system possible and just exactly what do we mean by that? What is and should be the immediate distribution of the cost of unemployment insurance upon the various parties concerned, and to what extent does the direct distribution of the cost correspond with the final incidence due to the process of shifting? Is a flat, uniform rate an inevitable aspect of a state-wide insurance scheme, or may there not be another method of achieving rate differentiation without sacrificing the interests of the wage worker? It is in these problems that really lies the fundamental issue of state pools against employer reserves.

\section{III}

The logical connection between an employer reserve plan and the question of insurability of unemployment is obvious. If unemployment insurance is impossible, some substitute plan without any insurance features becomes inevitable. It is curious that the argument had never arisen in that particular form in any one of the European countries. With much less experience to back them in IgII than we have in 1935, Great Britain, nevertheless, assumed that unemployment is insurable and proceeded with its first experiment. The argument as to uninsurability of unemployment, or at least of the impossibility of an actuarially sound system, cameoddly enough-from the very sanctum sanctorum of actuarial science and practicethe head office of the largest insurance company in the United States, if not in the entire world. This argument was precipitated in the fall of 1932 by the appearance of a series of pamphlets emanating from that company and written by its chief officers. They were all variations of the same theme: is unemployment insurable, is unemployment insurance feasible, etc. ${ }^{25}$

Even though the writer of these lines, in his official capacity as both member of, and actuary to, the Ohio Unemployment Insurance Commission, took a very definite attitude in opposition to these actuarial skeptics, it is nevertheless only fair to point out that in this respect he occupied a position of a somewhat splendid isolation. The insurance company's pamphlets were rapidly picked up by all of the insurance press as well as the general press, chambers of commerce, manufacturers' associations, etc. To a questionnaire sent out at this time by the Ohio Chamber of Commerce ${ }^{20}$ to

${ }^{25}$ Leroy A. Lincoln, Vice President, Metropolitan Life Ins. Co., Practicability of Unemployment Insurance (1932); Frederick H. Ecker, President, Metropolitan Life Ins. Co., Is Unemployment Insurable? (1932); James D. Craig, Actuary, Metropolitan Life Ins. Co., Is Unemployment Insurance Feasible and Practicable? (1932).

${ }^{20}$ The Chamber questioned the writer's right to speak for American actuaries. See, for instance, the publication of its Committee on Stabilization and Unemployment: Critical Analysis of the Report of the Ohio Commission on Unemployment Instrance (1932). In the preface to Unemployment Benefits and Instrance, published by the National Industrial Conference Board in I931, Magnus W. Alcxander, President of the Board, said: "Perhaps the most important conelusion to which this study has led is the thesis that unemployment is largely uninsurable. The risk of unemployment taken as a whole is not measurable, calculable or predictable."

The study indicates the significant fact that while the Wisconsin Plan was the major threat of a 
the IIo American and Canadian fellows and associates of the three main actuarial societies in the United States came rather startling results. Only two stated that a plan for general employment insurance could meet "standards of actuarial soundness" and denied that the problem was "inherently not one subject to actuarial appraisal." These two were identified in the report as the writer and "a consultant actuary." Yet a note accompanying the report is illuminating: "In 56 instances, actuaries stated that they were not by experience prepared to answer the questions." Taken by surprise, so far as technical study was concerned, the actuaries chose the safer path. However, the elasticity in the definition of "actuarial unsoundness" may absolve them from suspicion of dishonesty. Even workmen's compensation insurance after 25 years is still in a sense "actuarially unsound," since rates require and receive almost annual adjustment.

A third question inquired how long experience data would have to be accumulated to make an actuarial appraisal possible. The same two unregenerate sinners thought enough data already existed; 36 out of 73 responding thought enough could never be obtained, while the others specified periods ranging from 7 to roo years. In the light of this pessimism, one may point out, without malice, that although neither of the non-conformists served as actuarial expert in the framing of the Federal Act, the possibility of unemployment insurance was conceded in its very adoption. Nor is there any record of any actuary engaged by the various state commissions, investigating or executive, or by the large business associations as consultants, refusing to apply his knowledge and training to the solution of this "inherently" insoluble problem.

For after all, what is really meant by the phrase "an actuarially sound" insurance plan? In every branch of insurance, in every group of contingencies which that branch undertakes to deal with, there is found a variety of factors controlling the degree of hazard. Nor is there ever any accurate measure of complete hazard available in advance of the insurance experience. An "actuarially sound" life insurance plan does not automatically guarantee the solvency of a life insurance company. The same is true of all other branches. Such other factors as underwriting judgment are involved and above all a capital and a surplus is required as an additional guaranty to the policy holders.

When is an insurance plan "actuarially sound"? Is it only when the premiums accurately measure the hazard in advance so that there is neither a deficit nor surplus? An unexpected surplus endangers no one. The danger of absence of actuarial soundness lies only in the possibility of an insurance company's bankruptcy because of excess of losses and expenses over premium. No actuary and no actuarial system can offer a guaranty against that. For that reason constant vigilance is required over private insurance carriers.

possible unemployment insurance system, organized employers were against it and were very skeptical about the possibilities of stabilization. 
The moment unemployment insurance legislation has definitely provided, on one hand fixed premium rates, on the other hand fixed benefit scales, and then absolved the carrier, the state, from any residual responsibility beyond the fund itself, it has introduced factors of actuarial uncertainty which nothing can eliminate unless one of those three conditions is broken: somewhere there must be authority to adjust rates; second, to reduce benefit scales; or, third, to impose on the state some residual financial liability. As a temporary measure the right to borrow money can be granted. It is because these elementary principles of the insurance theory and practice were not understood or deliberately disregarded that the problem of actuarial soundness was made such an issue and, as an escape from it, came the Wisconsin plan.

It is not charged that that was the consideration in the minds of Professors Commons or Groves or Miss Brandeis. It is, however, asserted that the business interests were very clearly aware of the situation. They have continued to develop their enthusiasm for the employer reserve plan because it at once promises reduced rates to the fortunate or successful employer and assures the unfortunate or unsuccessful employer against excessive costs. In fact, the entire argument for that system as against the state pool and against the application of the insurance principle because of its assumed demoralizing effect upon the employer's care and caution-that argument might retain some logical force if with it went an unlimited responsibility upon the employer to the unemployed workman for the specified amount of unemployment in accordance with a fixed scale. The suggestion for such unlimited liability may sound very extreme, radical, and revolutionary, until one realizes that that is exactly the principle underlying workmen's compensation. A scale of benefits is fixed, the premium rate is unlimited. The incentive to the employer for saving through safety remains, but he is also given an opportunity of reinsurance. When so much is made by the Wisconsin group of the analogy between unemployment insurance and compensation-an analogy growing rather tenuous at times-it is significant that that analogy is never carried through in defense of interests of the employee as against those of the employer.

\section{IV}

So much for the problem of actuarial soundness, the insurability of the employer's risk and its bearing upon the question of the organization of the insurance fund. As our analysis has proceeded, I believe the point of view has been emerging that it is the cost as expressed in the premium rate and not the possible stabilizing influence of premium rate that really matters, and that it is because of the prevailing American system of placing the entire cost upon the employer, that this whole question has become the crucial one. Perhaps it isn't very gratifying to find that "How much is it going to cost the employer?" is so much more vital an issue than "What is the unemployed worker going to get out of it?" 
And yet this entire reasoning is based on the assumption that the cost will be born by the original party making the original payment, that this first bookkeeping cost represents the final incidence, that no shifting whatsoever takes place. If it should be found that the final incidence differs considerably from the original distribution of cost, the whole case may fall to the ground or require considerable theoretical modification. It is, therefore, necessary here to refer to this problem of cost.

The original cost falls either upon one or more of the following three, or possibly four, parties: (I) a tax upon the payroll payable by the employer; (2) a tax upon the pay envelope payable by the employee; and (3) some contribution, based either upon the payroll or pay envelope or in some other way related to the sum total of these contributions, which would be payable out of public resources, in this country, from the national or state or possibly local treasury, but in any case representing a financial burden upon the tax-paying public. Thus we have at least three potential sources of revenue and three economic groups to reckon with, the employer, the insured employee, and the tax payer. Either of the first two may also be a tax payer, of course. If all three sources of revenue are adopted, the largest proportion of the American people will be among the bearers of the cost.

But is the obverse equally true, that any one of the three groups may escape sharing the cost merely because it is freed from the direct obligation of making contributions? Apparently in the struggle that somewhat naïve point of view is taken for granted. The employee objects to an employee's contribution on the ground that his wages are too small anyway, that he bears the residual burden of unemployment. The employer argues that he cannot afford it. $\mathrm{He}$ is in the red anyway. When not in frank opposition to the entire plan, he urges an employee's contribution. But this struggle between employer and employee does not exhaust all the possibilities of conflict. Sometimes both, but more frequently the employee, especially the radical worker, urge placing the entire cost upon the treasury, as, for example, in the Lundeen Bill. ${ }^{27}$ If a contribution from the treasury meets with less enthusiasm from the employer, it is only because he quickly recognizes his own identity with the larger tax payer.

All these are more or less theoretical considerations. Actually the Federal Social Security Act makes only an employer's contribution obligatory. Employee contributions are not excluded and small ones have been adopted by five states. Apparently for the time being the question of a state or national contribution may be omitted from practical consideration. But does this superficial analysis exhaust the problem? The problem of shifting and incidence of compulsory charges is one of considerable complexity in the field of economics, especially as to taxation; and if social insurance charges be included in taxation (not necessarily an accurate assumption) comparatively little has as yet been done by economists either in the theoretical

${ }^{n}$ H. R. 2827, 74th Cong., Ist Sess. (1935). Other examples are the Townsend Plan and the position taken by Mr. Abraham Epstein of the American Association for Social Security. See note 29, infra. 
or inductive study of these processes. But in current discussion of the problem a very curious psychological attitude may be observed.

As a defensive attitude each one of the economic groups mentioned argues that the primary incidence will necessarily be the final one. The employer, the employee, the tax payer, all say: "I can't afford this additional charge. I can't afford to bear the cost. Let somebody else pay all or at least more." But when any one of the groups is trying to enlist another as its ally, it argues with equal conviction: "You are mistaken in assuming that I will pay the charge. I will certainly have to transfer it to your shoulders. You are as interested as I am to reduce my burden which will eventually become yours." 28

What are the possible processes of shifting? The employer threatens to reduce the wages. $\mathrm{He}$ is even more certain that he will have to unload upon the consumer. He further argues that the employee's contribution eventually will fall back upon him. It is only the defenceless tax payer that sees no way of shifting his burden upon anyone else, provided income is the basis of taxation. Real property and sales taxes may, of course, be shifted to tenants and consumers. But, from every angle, it is the consumer who has to pay the bill. This explains, for instance, the very forceful opposition of Mr. Abraham Epstein to any system of social insurance, unemployment or other branches, which does not include a contribution from the public treasury. ${ }^{29}$ The employer's contribution, that school argues, is merely a sales tax disguised. But does a government contribution necessarily meet the objection? It may if income be taxed; but supposing, as has now become the standard in many mid-western states, it is the sales tax that offers the easiest way of raising revenue for relief, old-age pensions, etc.? What advantage is there to the small consumer in paying the direct sales tax to the government, as against paying a quasi sales tax-if that it be-in increased prices?

We have as yet no objective, quantitative test of the actual processes of shifting, however obvious the process may be. Discussions of incidence and shifting largely remain on the usual level of complex, a priori reasoning. The pragmatic student is forced to the conclusion that shiftings probably take place in all possibile directions; but their degree is much less important than the definite fact that through them a much broader diffusion of the cost is achieved, and the community is thus induced to bear the cost of unemployment and other forms of social insurance in a least sensitive and objectionable way, with a greater approach to the paying capacity-the only reasonable basis of social distribution of costs.

The importance of this rather prolonged argument to the subject under discussion

28 "It is, therefore, our deliberate and unanimous opinion that a system of unemployment reserves to be satisfactory must cover industry generally, that the burden should be borne in such a way that unavoidable cost could be passed on to the public in the price of the product." Philadelphia Chamber of Commerce, Permanent Committee on Unemployment, Unemployment Reserves and Systematic Relief (Feb. 1932).

${ }^{20}$ See, for instance, Social Security, publication of the American Association for Social Security, Volume Io, No. I (Jan. Io, I936); also Epstein, Our Social Insecurity Act (Dec. I935) I72 HARPERs, 55. 
is just this: Of all various currents along which these costs are shifted, the most frequent one undoubtedly is that from the various factors of production cost such as wages, profits, even interest and rent into the price paid by the consumer. Whether the employer will admit it in discussion, he will undoubtedly strive to achieve that shifting once confronted with the inevitable charge. What then becomes of the argument of penalty for the bad employer and reward and inducement to the good? Certainly it falls entirely in its application to an industry as a whole. It might still remain as a differential between the efficient stable and inefficient unstable employer. In that case the consumer might have to bear the full weight of the marginal producer, thereby giving an additional profit to some employers without any relief to himself.

To sum up, at worst the cost of unemployment insurance, taking industry as a whole, represents but a minor charge upon the payroll and even a smaller charge upon the price of the product. The various processes of shifting and incidence are so complex that even an economic Einstein would be unable to follow them through. The connection between the insurance cost and the price, while real, may become very much attenuated. There are dozens of factors influencing price and the concept of a just and fair price is metaphysical rather than economic. In a practical business world these theoretical considerations can be of no importance to any one of the parties concerned.

\section{$\mathrm{V}$}

In the gradual approach to the central theme of this discussion we have seen that the organization of the insurance mechanism on an individual employer basis within each state fails to afford a sufficient basis of risk distribution, that the preventive and stabilizing effects of this plan are unreal, especially in view of the inadequate maximum contribution rate, and that the plan does not operate to apportion its costs among different products either accurately or advantageously.

Remains what? Remains the normal desire or effort to achieve some sort of fair proportion between the degree of hazard and the rate of contribution upon industry as the hazard-carrying factor. That is all that is left of the theoretical structure back of the Wisconsin plan. That is the final purpose of all the so-called merit-rating plans and suggestions which the very brief period of discussion of unemployment insurance in this country has already brought forth. If there are any sound arguments in favor of the Wisconsin plan, they all can be met through a system of merit rating.

Contrary to the general impression, the Federal Act does not establish or require a merit-rating system or any system of rate differentiation. It merely makes the application of such a system possible by somewhat complicated provisions for allowing rebates of the federal tax under certain conditions. Whether there is to be a merit-rating system or not is primarily a problem for the states. The relevant paragraphs of the Federal Act follow: 
"Section 9ro (a). A tax payer shall be allowed the additional credit under Section 909 with respect to his contribution rate under a State law being lower, for any taxable year, than that of another employer subject to such law only if the Board finds that under such law

"(I) such lower rate with respect to contributions to a pooled fund is permitted on the basis of not less than three years of compensation experience."

The first formulation of what has since come to be designated rather inaccurately as merit rating may be found in the draft of the Ohio Unemployment Insurance Commission's Bill of 1932 which, in 1933, succeeded in passing through the lower house of the Ohio Legislature, the draft of the bill for which the writer of these lines, to a very large extent, was responsible. Because of the obvious kinship between that original provision and those to be found in all the recent state acts, the language of the former may be quoted here in full. ${ }^{29 *}$

"Section 3, b. Until January r937, the contributions or premiums regularly payable by every employer into the fund shall be an amount equal to two percent per annum of his payroll. Thereafter the premium to be paid by each employer shall be determined by the classification, rules and rates made and published by the commission; and every employer shall thereafter pay at regular intervals fixed by the commission such premiums into the fund as may be ascertained to be due from him by applying the rules of the commission; provided that the premiums from an employer shall in no case amount to less than one percent per annum or more than three and a half percent per annum of such employers payroll.

"c. Classification of employments. For the purpose of establishing the premium to be paid by employers on and after January I, I937, the Commission shall investigate, group and classify employments, industries, and occupations with respect to the degree of hazard of unemployment in each, shall determine the risk of unemployment on the basis of the unemployment record and the fluctuations in the payroll of each employer and shall fix the rate of premium to be paid by each employer on an actuarial rating at the lowest possible figures consistent with the maintenance of a solvent insurance fund with reasonable reserve and surplus but within the limitations of maximum and minimum rates of contribution by the employers stipulated in section $3, \mathrm{~b}$. The commission shall have the power to apply that form of rating system which in its judgment is best calculated to merit or individually rate the risk most equitable to each employer predicated upon the record of employment and the fluctuations in payrolls of such employer and to encourage the prevention of unemployment; and shall develop fixed and equitable rules controlling same."

How great the influence of this formula upon legislation up to date has been, the following analysis will indicate. Of the ten acts: Two (Utah and Wisconsin) make no mention of the subject of merit rating, apparently depending upon the plant reserve plan for their rate adjustments. One (New York) merely provides for a study of the subject of rate adjustment by the Commission to be reported to the Governor and Legislature with recommendations. Seven (Alabama, California, District of Columbia, Massachusetts, New Hampshire, Oregon, Washington) em-

\$a Report of Ohio Commission on Unemployment Insurance, 1932, Pt. I, p. 70. 
body practically all the principles and a good deal of the langurage of the original Ohio Bill. ${ }^{30}$

Thus the statement seems justified that some provision for merit rating is destined to become the part of the rate-making system of unemployment insurance in the United States, particularly so long as the present Federal Social Security Act remains in force. While the provisions of that Act are rather involved, their intent is fairly clear; remembering that the rate foreseen in the Federal Act is $3 \%$ and that the employer is entitled to a credit for the contribution actually paid into the state fund up to $90 \%$ of the tax payable to the Federal Treasury or a maximum allowance of $2.7 \%$ of the payroll, he may still claim a credit up to the amount of $2.7 \%$ even though he has paid in less than that to the state fund, provided any one else in that state had actually paid $2.7 \%$ of his payroll or more. The intent is obvious. The employer who has earned a lower premium, whether because of advantages of a favorite classification or of individual merit rating, hall not be penalized by paying more to Uncle Sam because he had paid less to his own state. The conditions under which this extra credit is to be allowed, as outlined in Section 9ro, apparently represent a rather painstaking effort to make provisions for both the Ohio and Wisconsin types of legislation. It is extremely significant that the usual formula, both in the Federal Act and in the state acts, is the requirement of at least three years of compensation experience before such classifications or merit-rating schemes can go into effect-the standard first suggested by the Ohio Unemployment Insurance Commission. ${ }^{31}$

\section{VI}

An appraisal of these proposals for rate classification and merit rating requires a very brief consideration of the entire subject from at least two different points of view. How far is such rate differentiation economically or socially desirable? And second, is an actuarially sound system of merit rating possible?

Is it desirable, or at least necessary, or even important? Because of all the mysterious exact sciences actuarial science has retained the greatest atmosphere of mystery, there is a great deal of naive faith which the actuaries, like the augurs of old, rather enjoy maintaining among the laity. Or, not to be unfair, perhaps the insurance sales organization does that at the expense, and with the mild connivance, of the actuaries. It does help sell a life insurance policy to claim that down to the very last cent the premium has been scientifically computed by actuaries, that there

${ }^{30}$ The language of the provisions dealing with merit rating is practically identical in the Massachusetts Act, Mass. Laws I935, c. 479 , $\$ \$ 4,5$, and the District of Columbia Act, Public, No. 386, 74th Cong., Ist Sess. (1935) $\S_{3}$ (b); also in the California Act, Cal. Stat. 1935, c. 352, $\$ 39,42$, and that of New Hampshire, N. H. Laws, c. 99, $\$ 7$, ro; and finally in the acts of Alabama, Ala. Laws 1935, Sen. B. No. 395, $\$ 4$ (c), Oregon, Ore. Laws 1935, H. B. No. 7I, \$16 (d), and Washington, Wash. Laws I935, c. I45, $\$ 5$ (4). Nor are the differences between the language in those three sets of acts of any decisive theoretical significance and for limitations of space those differences will not be discussed here.

"The writer has called attention to the influence of the Ohio Commission of 1932, and its report, upon all American thinking as to the actuarial aspects of unemployment insurance, not to claim credit therefor but, on the contrary, to admit very frankly all the difficulties which this plan of merit rating may entail, without any desire on his part to avoid his share of responsibility for them. 
simply cannot be a mistake-yet some companies accumulate surpluses of millions and others go to the wall. But how much of a real adjustment is there to the comparative degree of hazard, even in life insurance? There is, of course, according to age. But the venturesome salesman who travels by airplane in all kinds of weather and the sedentary minister of the gospel, who never ventures out of his study without galoshes and umbrella and a sweater and a muffler, pay the same rate. Once insured, you may live in the sunny clime of Hollywood or on the storm-beaten shores of Lake Michigan, but if you are the same age you pay the same rate. Unfair? Unscientific? Undoubtedly so, but in the final analysis whom does it particularly harm? The reason? The extreme technical difficulties of a more scientific rate structure. Also perhaps a tradition, which requires in life insurance a very complicated consideration of every day of your age but allows a disregard of every other consideration.

There isn't any branch of insurance of which the same criticism might not readily be made. In automobile insurance a man may drive his car for 2,000 miles or 50,000 miles a year. If it is a Chevrolet of 1934 he pays the rate on that machine and that is all there is to the rate adjustment, though the actual hazard in one case may be one hundred times as large as the other. Once you have received your liability policy, the question of your eye-sight, your foresight and your hind sight, your hearing, your alcoholic habits, or even your amorous technique has no influence upon the policy. Under workmen's compensation each state has a classification schedule including anywhere from 1,000 to 2,000 different classifications. The exposure on each is so small that it would really take roo years before an average for that particular classification in that particular state could be obtained. A comparison of the computed "pure premium" with the actual schedule rate would amuse the actuaries were they not prepared to expect no more. Examples could be multiplied. A fair insurance rate is an abstraction. It is an ideal which is never realized. There is no such thing as an abstract and perfect justice. What may be known is the extent to which the entire rate structure meets the needs of the total hazard. As to differences within the structure, to a large extent they remain matters of judgment, except in so far as they may have a pragmatic effect of achieving or preventing results. Why place before a new form of insurance strict requirements which even the oldest and best-tested forms of insurance could not meet?

Is rate classification desirable? Of course, if the sense of justice of the community requires it. We have been taught to recognize differences of cost of life insurance due to the initial age at beginning of insurance, to recognize the hundred-fold difference in industrial accident hazard between a clothing shop, with an electric needle as the most threatening piece of machinery, and the construction of a suspension bridge across San Francisco Bay. If these differentiations were suddenly abandoned, our sense of justice would be outraged.

But, on the other hand, used for 25 years to a uniform charge for unemployment insurance, the British or the Germans or the Austrians accept it as a matter of course, 
though occasional grumbling is heard. When insurance by industry or merit rating or classification rates is suggested, even the employers fail to grow very enthusiastic or at least the wishes of those who might profit by it are cancelled by the fears of those who might lose. And while the essential justice of the claim for some rate differentiation need not be denied, the whole question in American discussion has been given consideration entirely out of line with its intrinsic importance. Surely the comparatively slight differences, as they might affect either profits or price or the consumers' interest, are as naught in comparison with the advantages of some form of unemployment insurance. By all means rate classification and merit rating, if a practical system can be devised, but under no circumstances should it become a conditio sine qua non.

What is the real explanation of the failure to develop some form of rate classification for unemployment insurance in Europe when workmen's compensation practice has served as a precedent for several decades in every European country? Simply that under compensation the employers' liability for the accepted scale was unlimited. Such unlimited liability for unemployment would have frightened the employers into panic. It was necessary, therefore, to take the very dangerous step of embodying both the rate of contribution and the scale of compensation within the written law, and then trust to the Almighty that the algebraic formula would work out. As a matter of fact it seldom has. The story of the failure of the formula in English legislation is too well known to be repeated here. But with this principle of a strictly limited maximum rate once accepted, any discussion of a scientific rate differentiation appears somewhat naive. At most the spread in all the state laws is somewhere between $1 \%$ and $3 \frac{1}{2} \%{ }^{32}$ as contrasted with a spread from a few cents on $\$$ roo of payroll and, say, up to $\$ 15$ which scientific rating would require. If reliable statistics of distribution of all industries according to cost of unemployment insurance were obtainable, it would probably be found that some $10 \%$ or $20 \%$ would be between the legal minimum and maximum limits and the rest either below the minimum or over the maximum. What is the scientific or social value of such a limited degree of rate adjustment? It may be valuable only so far as it may serve as an instrumentality for stabilization. $^{33}$ The theoretical argument in favor of rate classification and merit rating is, therefore, the same as for the employer reserve plan, but it is not subject to the same limitations, or not at least to the same degree. It does not place the interests of the unemployed worker in jeopardy.

sa "Let us assume that the Commission, would be able to determine actuarially the proper premiums to be paid by each class of employers for the maintenance of a solvent insurance fund. The effect of $x \%$ to $31 / 2 \%$ limitation would be to destroy the merit basis of all rates so determined since there would be no classes above $3 \frac{1}{2} \%$ and this would require a contribution higher than the proper actuarial rates to which those with stable employment would otherwise be entitled. Therefore the actuarial character of every rate is entirely destroyed." Ohio Chamber of Commerce, Committee on Stabilization and Unemployment, Critical Analysis of the Report of the Ohio Commission on Unemployment Insurance (I932).

ss "The payroll tax [with merit rating] should become a compelling incentive to employers to work out group and industry-wide programs." Feldman, Application of Merit Rating to Unemployment Insurance, Social Security in the ÚNIted States, 1935, p. 164, at p. 167 . 
But is a system of merit rating possible? Can it be made scientific? Can it be made actuarially sound? Again we are dealing with a series of ill-defined terms and the definition is necessary before a definite answer can be given.

To begin with, it must be understood that the expression "merit rating," first used in this connection in the Ohio Bill, includes several forms of rate adjustment not all of which properly should be designated as merit rating. ${ }^{34}$ Rate differentiation, according to classification of hazard by industry, is one thing; a priori modifications of the rate in consideration of certain conditions for better or worse, which may exist in individual plants-a method known in fire or compensation insurance as schedule rating-is another; a system of rate credits or penalties based upon the actual experience of the individual employer-known as experience rating-is again another. Only the latter two, schedule and experience rating, carry a certain ethical connotation which may be included under the formula of merit rating. There may be a merit or demerit in running a good or bad plant. There may be merely luck as well as merits in having had good or bad experience. But there is no particular "merit" in the banking business as against the construction business.

When can a system of rate differentials be described as scientific? There is no absolute but only a relative test in so far as the scheme abandons mere guess work or "underwriting judgment," or the use of rate differentials for business-getting-all conceptions borrowed from private competitive insurance. In so far as it seeks to utilize objective facts of experience it may be described as becoming scientific. After all, insurance is not astronomy. It does not expect to operate with the same certainty and accuracy.

Finally, what are the minimum demands of actuarial soundness? If the demand be that each rate by itself prove an absolutely accurate reflection of the degree of hazard to be expected, that is an ideal unattained in any of the old branches of insurance. ${ }^{35}$ An insurance scheme is actuarially sound so long as the rate structure taken as a whole provides ample but not, knowingly, excessive resources for the payment of losses. And even the latter qualification may be waived in a mutual insurance system with distribution of the surplus.

It follows, therefore, that an actuarially sound system may be provided so long as it is not expected to be absolutely accurate. But how, then, is this more or less scientific rate structure to be prepared?

It is an extremely interesting situation that those very circles which so strenuously denied that unemployment is an insurable risk at all, who denied that even a uniform, fairly accurate, premium rate can be determined, are now blandly demanding and legislating for much more difficult schedule of rates according to individual

st See article by Professor Herman Feldman, supra note 33, one of the few writers who clcarly differentiates between rate differentiation among industries as a whole and merit rating of individual employers. He thinks that "the former involves many more complex administrative and economic problems than mere merit rating." Id. at p. 166.

${ }^{35}$ Professor Solomon Blum, in his book, Labor Economics, thinks that in regard to unemployment insurance merit rating is impossible because of the absence of adequate data. BLUm, Lasor Economes (1925) 176. 
hazards. Certainly the actuarial difficulties of the latter are very much greater. It may well be that the total amount of unemployment can be insured against while the variable degrees of unemployment in a thousand and one different industries may remain baffling to the actuary.

Without attempting here to discuss such methods as have already been suggested for determining unemployment insurance rates (primarily the so-called Rubinow formula, explained at great length in the Ohio Unemployment Insurance Commission's report), it is enough to point out to the lay reader that any such rate must be based upon the assumption of a certain unemployment rate, a proportion between the unemployed and employed within a certain territorial unit. At least approximately the writer was enabled to do that for the State of Ohio because of an exceptionally complete series of employment data for that state, compared with approximate data as to the total available labor force. ${ }^{38}$ The rate obtained on the basis of some ten years of experience was approximately $13.5 \%$. How much more difficult would be a similar determination for individual industries or plants, even if all the necessary data on employment were available for each industry or plant. It is extremely difficult, at least in our country with the well-known mobility of labor, to determine what the available labor force for that industry is. It may be done, at least approximately, for a highly skilled trade or occupation. One might determine what percentage of instrument makers or lens grinders are out of work. But the common laborer shifts from one plant to another. How can the fluctuations of employment of such labor in one plant indicate the degree of unemployment for which it is responsible? Imagine for a moment two plants in the same locality, both employing a considerable amount of unskilled labor and dovetailing into each other seasonally. The result might be a very high rate of labor turnover for both plants with comparatively little unemployment for the two if their experience were pooled together. What, then, is the basis of the promise of better rate adjustment to the degree of unemployment hazard, as suggested by Ohio and followed by at least seven of the states?

What did the Ohio Commission promise? It promised that within three years: (I) the Commission would "classify employments, industries and occupations" from the point of view of unemployment hazard; (2) would "determine the risk of unemployment on the basis of the unemployment record and fluctuations in the payroll of each employer"; (3) would "fix the rate of premium to be paid by each employer" (presumably employments as well as occupations); and (4), while so doing, would yet hold to a minimum of $\mathrm{x} \%$ from the employer, even though the actual risk might justify a much lower rate, and to a maximum of $3 \frac{1}{2} \%$, even though the actual risk might justify a very much higher rate.

There was obviously no magic in the proposal of three years of experience nor any solid basis for the estimate, except that it was more reasonable than the intervals

\footnotetext{
${ }^{25} 2$ Report of Ohio Unemployment Insurance Commission, 1932, Pp. 206-212, tables IV, V, chart I.
} 
of from seven to Ioo years, proposed by other actuaries. It is gratifying, though somewhat bewildering, to the actuary of the Ohio Commission of 1932, to find that in almost all the states with merit-rating provisions, the same three-year period has been adopted, following the standards in the Federal Act. Unfortunately there is little to support the hypothesis that the adoption of this formula was a result of careful research. The man courageous enough to make a guess will usually find ample imitators. It is, however, only fair to admit that, from the point of view of any reasonable degree of accuracy, a three-year period might suffice for the general average level of hazard, but certainly would not furnish statistics on individual industries, occupations, trades, and particularly individual plants, large or small. Consider what might happen to the rate structure if those three years accidentally were to be three fat years rather than lean years. As the average rate is based upon both fat and lean years, with the inclusion of at least one serious crisis, the experience of three good years might result in rebating the rates on most of the industries, thus cutting very heavily into the basis of a reserve to be accumulated for the depression era. The reservation made in the Ohio Bill that the actuarial ratings should be "at the lowest possible figure consistent with the maintenance of a solvent insurance fund with reasonable reserves and surplus," sounds both scientific and desirable indeed, but I fear must remain in the domain of pious wishes.

Nevertheless, obvious differences between industries may be disclosed, and in so far as these confirm popular conceptions of the degree of their regularity or irregularity, such experience may be useful. If it is considered necessary-and apparently today it is-rate differentiations by industries may be introduced even after the short period of three years, always provided that: (I) No high degree of accuracy is claimed for them. (2) No effort is made to rebate for the entire difference between the original rate and the experience. (3) And finally, rate differentials are not granted on a permanent basis but remain subject to changes both upward and downward, in accordance with the needs of the case.

Frankly, then, the admission is here made that merit rating, far from soon becoming highly accurate, may, if thought necessary, be used as a mechanism of reward or punishment and that its effect should be studied primarily from the point of view of its effectiveness as a stabilizing factor. Whether the enthusiasm for merit rating will continue to sway the American employer as soon as he finds out that it necessarily must lead not only to merits but also demerits, not only to rate reductions but also rate surcharges, may remain a question, but it is a question that does not demand an immediate answer.

In the final analysis, therefore, the cautious New York provision, merely authorizing the Commission to make a report, and the much more precipitate action of the other seven states in almost making rate differentials mandatory within three years, may not be so very far apart. Just as New York may be induced to establish a moderate system of industrial rate differentials, so perhaps the other states may also be induced to mitigate the mandatory character of their provisions. 
VII

In the above discussion, for purposes of simplification, state pools and employer reserves were presented as mutually exclusive alternatives. Actually neither in the Federal Act itself nor in most of the state acts already adopted is this alternative presented so sharply. The possibility of various combinations between these two and other plans is left open. In fact, with only ten acts, several such combinations exist already, and the door is left open to a variety of others.

Among these other plans, perhaps the most important, theoretically, is the guaranty of employment. Here again the Federal Act, in its effort at extreme catholicity, introduced this principle largely because it was found in the original Wisconsin Act, which contained quite detailed and comprehensive provisions enabling the Commission to exempt any employer who guaranteed under an approved plan a certain minimum of employment to all his employees. ${ }^{37}$ The specific amount of time guaranteed in the Wisconsin Act was 40 weeks at 30 hours (or approximately I,200 hours of paid work throughout the year) with a reduction of one hour per week for each added week. The theoretical significance of these provision is their assumption that an employer can give such guaranties and that, if he does, the problem of unemployment is solved for his labor force. Accepting that assumption, it is also significant that the working time guaranteed is apparently considered as a satisfactory, normal condition of employment. Assuming a normal annual rate of 2,000 hours for full-time work, the actual amount of work guaranteed may thus fluctuate between I200 hours ( 40 times 30 hours) or $60 \%$ of the full-time normal, and 1,000 hours ( 50 times 20 hours) or $50 \%$. The assumption that all the purposes of stabilization and regularization and prevention of unemployment have been satisfactorily met on the basis of a part-time employment of $50 \%$ to $60 \%$ offers an interesting commentary on the whole conception of unemployment prevention in this country.

Naturally the Federal Act cannot exempt entirely employers from the action of the federal payroll tax. It therefore offers no complete exemption to guaranteed employment plans but only the opportunity for additional credits as against the tax. Section gIo (a) (2) provides:

"A tax payer shall be allowed the additional credit under Section 909, with respect to his contribution rate under a State law being lower for any taxable year than that of another employer subject to such law only if the Board finds that under such law-

"Such lower rate, with respect to contributions to a guaranteed employment account, is permitted only when his guaranty of employment was fulfilled in the preceding calendar year and such guaranteed employment account, amounts to not less than $71 / 2$ per centum of the total wages payable by him in accordance with such guaranty with respect to employment in such State in the preceding calendar year."

Furthermore, Section 91o (c) (3) defines a guaranteed employment account quite clearly as an account in an unemployment fund, and not merely a promise of a guaranty. The same limitations of $3^{0}$ hours for $4^{0}$ weeks or less hours for more "WIs. Stat. (1933) §ro8, 15 (r). 
weeks within each twelve months are provided. Moreover, this guaranty need not commence until after a probationary period of some 12 weeks of service. Thus an employer may still retain a considerable labor turnover provided he concentrates that turnover as far as possible within his probationary force and limits the guaranty, such as it is, to his permanent staff. Under this provision a guaranteed employment account differs little from an employer reserve account except that the benefits to the unemployed are subject to rather severe restrictions, for a partial unemployment of some $50 \%$ may go entirely uncompensated, and even total unemployment for 12 weeks in each year. These provisions are, to that extent, merely a polite intrusion of the employer reserve principle into the state pool plan.

Apparently very few states have as yet adopted these particular provisions. Oregon has a schedule of guaranteed employment practically copied from the Federal Act, with some rather obscure provisions as to what the continued rate of payment of such exempt employers to their guaranteed employment account should be. ${ }^{38}$ California has a slightly different schedule varying from 42 weeks at 36 hours or a total of I512 weeks, down to 50 weeks at 20 hours or a maximum of rooo hours guaranteedapproximately from $75 \%$ to $50 \%$ of annual full-time employment. ${ }^{30}$

It is difficult at this time to appraise exactly the full value of this particular form of exemption or others by means of which individual employers may, in the hope of reducing the insurance cost to themselves, even before rate classifications have been adopted, withdraw less hazardous plants from the general state plan. Obviously, such withdrawals, whatever the legal subterfuge may be, may reach the degree at which the state pool as such would be jeopardized. This fact would then be used as an argument against the solvency of state funds. Only experience will demonstrate that.

There is one redeeming feature about the vagaries of the federal and state acts already adopted. Practically all of them are shees "inventions," based upon a merely theoretical, a priori consideration of the operation of a complicated insurance organization. One may retain the hope that as these somewhat fanciful plans come up for definite administrative regulation and approval, and particularly after some experimentation with them, amendments will not be as slow in following as they have been in the experience of American workmen's compensation legislation. While prophecies are proverbially difficult, one may look forward to a gradual stabilization of the unemployment insurance system into state pools with greater rate differentiation, according to industrial classification and with only minor attention being paid to individual plant experience; with gradual elimination of exemptions; perhaps with greater leeway for state authorities to vary contribution rates among much wider margins; and perhaps with the gradual building up of an interstate reinsurance fund to be administered by federal authority with a certain residual federal financial responsibility.

${ }^{3}$ Ore. Laws 1935, H. B. No. 71, $\$ \$ 2$ (o), I6 (b).

${ }^{20}$ Cal. Stat. I935, c. 352, \$47. 